\title{
Effect of Autumn Cutting Date on Regrowth, Turning Green, Yield and Quality of Leymus chinensis Grassland in Songnen Plain, Northeast China
}

\author{
Yantao Song1, Wuyunna1, Daowei Zhou ${ }^{2 *}$ \\ ${ }^{1}$ College of Environment and Bioresources, Dalian Minzu University, Dalian, China \\ ${ }^{2}$ Northeast Institute of Geography and Agroecology, Chinese Academy of Sciences, Changchun, China \\ Email: ${ }^{\star}$ zhoudaowei@iga.ac.cn
}

How to cite this paper: Song, Y.T., Wuyunna and Zhou, D.W. (2018) Effect of Autumn Cutting Date on Regrowth, Turning Green, Yield and Quality of Leymus chinensis Grassland in Songnen Plain, Northeast China. American Journal of Plant Sciences, 9, 185-195.

https://doi.org/10.4236/ajps.2018.92016

Received: December 5, 2017

Accepted: January 22, 2018

Published: January 25, 2018

Copyright $\odot 2018$ by authors and Scientific Research Publishing Inc. This work is licensed under the Creative Commons Attribution International License (CC BY 4.0).

http://creativecommons.org/licenses/by/4.0/

\begin{abstract}
A field study was carried out to quantify the effects of different cutting time on Leymus chinensis population and community characteristic in Songnen grassland of northeast China from August, 2006 to August, 2007. The treatment interval was ten days with the remaining stubble height of $5 \mathrm{~cm}$ from 15th August to 4th October in 2006. Results showed that the L. chinensis made up about $90 \%$ of the dry matter of aboveground biomass, and there were about ten species in the $L$. chinensis community in the $1 \mathrm{~m} \times 1 \mathrm{~m}$ plot. The L. chinensis and Kalimeris integrifolia regrew rapidly after autumn cutting in 2016. In the second year, the coefficients of the community similarity were high between the different cutting time treatments. The density, height, aboveground biomass, stem/leaf ratio, and crude protein of $L$. chinensis were not significant at the turning green stage and harvesting stage, the companion species of $L$. chinensis community contained higher crude protein, but the crude protein of the plant community were not significant. Thus, considering the weather factor for haymaking, the harvest dates should be concentrated from the middle ten days of August to the first ten days in September.
\end{abstract}

\section{Keywords}

Leymus chinensis, Autumn Cutting, Hay Yield, Quality, Songnen Grassland

\section{Introduction}

The Songnen plain covers the western parts of Heilongjiang, Jilin and Liaoning provinces of northeastern of China, existing an area of about $170,000 \mathrm{~km}^{2}\left(43^{\circ} 30^{\prime}\right.$ 
to $48^{\circ} 40^{\prime} \mathrm{N} ; 121^{\circ} 30^{\prime}$ to $127^{\circ} 00^{\prime} \mathrm{E}$ ), about $40 \%$ of which is Leymus chinensis grassland [1] [2]. L. chinensis is a perennial rhizome grass and widely distributes in the eastern end of the Eurasian steppe zone, with the main locations in China being in the Songnen plain and the eastern part of the Inner Mongolian plateau [3]. This species is ideal for grazing and forage because of its high palatability and nutrition [4]. The usual growing conditions in Songnen plain produce superior herbage both in quality and in quantity, thus, this type of grassland is one of the best suited in northern China for the grazing land or cutting field [5].

The climate type of Songnen plain is a semi-arid, temperate continental monsoon, the winter is long and cold, the summer is short and warm, the raining period concentrates on from June to August, the growing season in this region is mainly from April to October [6]. And the primary productivity is correlative with environmental factors [7], especially the precipitation from April to July or aridity index [8]. The primary productivity of the forages reaches the maximum usually at the middle or last ten days of August [9] [10].

Cutting is one of the main ways to utilize and manage grassland [11] [12], this way can supply the forage for livestock in winter and next spring and make sure them live through the long and cold winter [13], and cutting once per year is advisable in Songnen grassland [11] [14], because cutting two times a year would lead some harmful effects on the yield and environment of the grassland even adding the fertilizer and water to the grassland [15] [16]. So the farmer usually harvests the forage from later summer to early winter in order to gain the maximal yield and quality, and this is the best time for making hay of Songnen grassland because of the good weather, and the height of the remaining stubble usually is $4-5 \mathrm{~cm}$ [5]. But different cutting dates may not only effect on the grass regrowth, and biomass at the current year [17] [18] [19], but also effect on the turning green date, biomass, layering distribution of the biomass for the next year [11] [14] [20]. Previous studies have showed that all the cutting dates run through the whole growing season, such as moderate levels of spring defoliation could improve winter range forage quality [21], cutting in May or June decreased vegetative tillers, but increased crude protein content and in vitro dry digestibility [22], autumn harvest date gained different quality forage [13], winter cutting or grazing didn't affect the spring ground or spring forage yield if it was accomplished before spring growth [23]. However, the time interval was always long, how different autumn relatively concentrated harvest dates effects on L. chinensis community in Songnen grassland had not been reported.

The objects of this study were: a) determining the cutting dates effecting on the regrowth at the end of the current year, b) assessing the effect of cutting dates on the grassland for the next year, c) seeking the optimal harvest dates of the grassland.

\section{Materials and Methods}

\subsection{Study Site}

Experiments were conducted on the cutting field at the Songnen Grassland Eco- 
logical Research Station, operated by Northeast Normal University and located at latitude $44^{\circ} 40^{\prime} \mathrm{N}$, longitude $123^{\circ} 44^{\prime} \mathrm{E}, 150 \mathrm{~km}$ northwest of the provincial capital, PR Changchun, China. The study area has a frost-free period of about 140 days. The mean annual temperature ranges from $4.6^{\circ} \mathrm{C}$ to $6.4^{\circ} \mathrm{C}$, varying from $-16^{\circ} \mathrm{C}$ in January to $25^{\circ} \mathrm{C}$ in July. The annual precipitation is $350-450 \mathrm{~mm}$ and. The annual potential evapotranspiration is approximately three times as much as the mean annual precipitation. The main soil type of the area is a meadow chernozem with $\mathrm{pH}$ is $7.5-9.0$ and organic matter is $3.5 \%-6 \%$ in the surface layer. The grassland is continual cutting field and the dominant species is L. chinensis [1] [3] [17].

\subsection{Experimental Design and Sampling Methods}

The experiment was from the August $15^{\text {th }}, 2006$ to August $11^{\text {th }}, 2007$. The cutting date was from August $15^{\text {th }}$ to October $4^{\text {th }}$ in 2006 with every 10 days interval. The experiment used a randomized complete block design, the plots area were $5 \mathrm{~m} \times$ $5 \mathrm{~m}, 5$ replications, and the height of the remaining stubble was about $5 \mathrm{~cm}$ using the reaphook. Then we investigated the regrowth character of the different treatments in October at the current year, including the regrowth plant height, leaf number, and aboveground biomass of $L$. chinensis, constitute of species, and density with the sampling area was $1 \mathrm{~m} \times 1 \mathrm{~m}$ in each plot.

We settled two $1 \mathrm{~m} \times 1 \mathrm{~m}$ subplots in each plot the on May $10^{\text {th }}$ in next year after the grassland had been turning green. The first month we measured the length of the second leaf, the height of $L$. chinensis in each sample, and harvested the aboveground biomass of one of the two samples. We harvested the aboveground biomass of the other settled subplots on August $11^{\text {th }}, 2007$, measured the height of $L$. chinensis, the species composition of the plant community, the aboveground biomass of each species and the stem/leaf of L. chinensis. We also made the background investigation of the grassland on August $16^{\text {th }}, 2006$, the plots were $1 \mathrm{~m} \times 1 \mathrm{~m}$ with 10 replications.

The method of harvesting aboveground biomass was using the scissors to cut the plants getting closing to the ground. All the samples were oven-dried at $65^{\circ} \mathrm{C}$ $\mathrm{C}$ for at least 48 hours immediately after harvest and weighted. The crude protein percentage was determined in duplicate using Kijldahl method (Kjeltec Analyzer Unit, FOSS TECATOR).

\subsection{Statistical Analysis}

The similarity of community was calculated by Sørensen Coefficient $\left(I S_{s}=\right.$ $2 \mathrm{C} /(\mathrm{A}+\mathrm{B}), \mathrm{A}$ and $\mathrm{B}$ are the number of the species of the two communities, $\mathrm{C}$ is the number of the common species) [24]. The effect of height, leaf number, leaf length, density, aboveground biomass and stem/leaf data were analyzed by ANOVA with Tukey test for multiple comparisons among the treatments. All statistical analyses were performed using SPSS 13.0 (SPSS Inc., Chicago, USA) at 0.05 level. 


\section{Results}

\subsection{Background Information at the Study Site}

The species number of the community was few, and there were about nine species in $1 \mathrm{~m}^{2}$. The fresh and dry weight of $L$. chinensis made up $86.26 \% \pm 2.25 \%$ and $89.70 \% \pm 1.70 \%$ of the plant community aboveground biomass, the plant community fresh and dry weight were $517.17 \pm 35.40 \mathrm{~g} / \mathrm{m}^{2}$ and $297.66 \pm 18.99$ $\mathrm{g} / \mathrm{m}^{2}$, separately. The main companion species were Kalimeris integrifolia, Echinochloa crusgalli, Eragrostis pilosa, Setaria viridis, Lathyrus quinquenervius, Carex duriuscula, Scriprs fluriatilis, Eleocharis intersita, and Polygonum sibiricum. The height and density of $L$. chinensis were $31.47 \pm 1.12 \mathrm{~cm}$, and $1176 \pm 66$ plants $/ \mathrm{m}^{2}$.

\subsection{Regrowth Character at the End in $\mathbf{2 0 1 6}$}

The values of regrowth character of $L$. chinensis descended as the cutting date putting off (Table 1). The height descended quickly after the first cutting date, which was $12.05 \pm 0.52 \mathrm{~cm}$. There were no significance between August $25^{\text {th }}$ and September $4^{\text {th }}$, and between September $4^{\text {th }}$ and September $14^{\text {th }}$, but there was significant difference between August $25^{\text {th }}$ and September $4^{\text {th }}$. And the shortest height was at the last two cutting dates, September $4^{\text {th }}$ and October $4^{\text {th }}$. The leaf number was significant different among the cutting dates $(P<0.05)$. The cutting dates could be divided into three periods and there were significance in any two of the three periods. The regrowth density of $L$. chinensis was much less than that without cutting $\left(1176 \pm 66\right.$ plants $\left./ \mathrm{m}^{2}\right)$, the highest one was just litter more than half of that without cutting, the others were less and less, and L. chinensis density of the last cutting date just was as one fifth of that without cutting. The regrowth of the aboveground biomass were also light, and the heaviest was 18.44 $\pm 1.44 \mathrm{~g} / \mathrm{m}^{2}$ after the first cutting date.

The regrowth of other companion species were mainly $K$. integrifolia and $C$. duriuscula (Table 2). But the height of the species was short. The species such as Artemisia scoparia just appeared in some polts, and the cutting date on August $15^{\text {th }}$ had the most regrowth species number.

\subsection{Turning Green Stage in the Second Year}

The $L$. chinensis was at the third-leaf stage when we measured the plot on May $11^{\text {th }}, 2007$ after the grassland turning green, and we measured the second leaf length of $L$. chinensis (Table 3 ). The second leaf length were no significance among the first three cutting dates, there were significant difference on August $25^{\text {th }}$, September $14^{\text {th }}$ and September $24^{\text {th }}$. And the trends were descending as the cutting dates delayed though most of them were not significant (Table 3).

The height of $L$. chinensis population was lowest on September $24^{\text {th }}$, but most of the treatments were not significant, the significant dates were between August $15^{\text {th }}$, August $25^{\text {th }}$ and September $24^{\text {th }}$ (Table 3 ). 
Table 1. The regrowth character of $L$. chinensis.

\begin{tabular}{ccccc}
\hline Date & Height $(\mathrm{cm})$ & Leaf number & Density $\left(\right.$ plants $\left./ \mathrm{m}^{2}\right)$ & Biomass $\left(\mathrm{g} / \mathrm{m}^{2}\right)$ \\
\hline 15 Aug & $12.05 \pm 0.52 \mathrm{a}$ & $3.8 \pm 0.12 \mathrm{a}$ & $629.0 \pm 49.04 \mathrm{a}$ & $18.44 \pm 1.44 \mathrm{a}$ \\
25 Aug & $8.48 \pm 0.47 \mathrm{~b}$ & $3.7 \pm 0.06 \mathrm{a}$ & $535.8 \pm 42.75 \mathrm{ab}$ & $14.28 \pm 1.14 \mathrm{~b}$ \\
4 Sep & $7.22 \pm 0.19 \mathrm{bc}$ & $3.0 \pm 0.08 \mathrm{~b}$ & $493.4 \pm 57.85 \mathrm{ab}$ & $5.12 \pm 0.60 \mathrm{c}$ \\
14 Sep & $6.34 \pm 0.22 \mathrm{c}$ & $2.6 \pm 0.09 \mathrm{~b}$ & $409.0 \pm 42.70 \mathrm{bc}$ & $3.50 \pm 0.37 \mathrm{c}$ \\
24 Sep & $4.04 \pm 0.30 \mathrm{~d}$ & $1.9 \pm 0.14 \mathrm{c}$ & $383.2 \pm 33.72 \mathrm{bc}$ & $2.94 \pm 0.26 \mathrm{c}$ \\
4 Oct & $4.01 \pm 0.15 \mathrm{~d}$ & $1.7 \pm 0.15 \mathrm{c}$ & $236.4 \pm 42.53 \mathrm{c}$ & $1.71 \pm 0.31 \mathrm{c}$ \\
\hline
\end{tabular}

Means \pm SE with different letters were significantly different at 0.05 level.

Table 2. The regrowth density of the species excluding $L$. chinensis.

\begin{tabular}{|c|c|c|c|c|c|c|c|c|}
\hline \multirow[b]{2}{*}{ Date } & \multicolumn{8}{|c|}{ Species density (plants $/ \mathrm{m}^{2}$ ) } \\
\hline & $K$. integrifolia & C. duriuscula & $\begin{array}{l}\text { Artemisia } \\
\text { scoparia }\end{array}$ & $\begin{array}{c}\text { Ambiytropis } \\
\text { muitiflora }\end{array}$ & $\begin{array}{c}\text { Ixeris } \\
\text { chinensis }\end{array}$ & $\begin{array}{c}L . \\
\text { quinquenervius }\end{array}$ & $\begin{array}{l}\text { Potentilla } \\
\text { flagellaris }\end{array}$ & P. sibiricum \\
\hline 15 Aug & 53.6 & 70.8 & 0.4 & 0.4 & 4.2 & 2.6 & 0.2 & -- \\
\hline 25 Aug & 37.6 & 75.2 & -- & -- & 0.2 & -- & -- & -- \\
\hline 4 Sep & 40.4 & 82.4 & 0.2 & -- & -- & 1 & 7.6 & 0.4 \\
\hline 14 Sep & 29.0 & 45.8 & -- & 0.4 & -- & -- & 14.6 & 0.2 \\
\hline 24 Sep & 0.2 & 53.0 & -- & -- & -- & -- & 3.0 & -- \\
\hline $4 \mathrm{Oct}$ & 1.0 & 88.0 & 0.2 & -- & 0.2 & 0.2 & 2.2 & -- \\
\hline
\end{tabular}

--: Meant that the species did not grow in the investigated plots.

Table 3. The turning green characteristic of $L$. chinensis.

\begin{tabular}{ccccc}
\hline Date & Second leaf length $(\mathrm{cm})$ & Height $(\mathrm{cm})$ & Density $\left(\right.$ plants $\left./ \mathrm{m}^{2}\right)$ & Aboveground biomass $\left(\mathrm{g} / \mathrm{m}^{2}\right)$ \\
\hline 15 Aug & $6.92 \pm 0.18 \mathrm{ab}$ & $9.33 \pm 0.14 \mathrm{a}$ & $674.6 \pm 68.6 \mathrm{a}$ & $20.55 \pm 2.57 \mathrm{a}$ \\
25 Aug & $7.11 \pm 0.21 \mathrm{a}$ & $9.51 \pm 0.19 \mathrm{a}$ & $784.0 \pm 91.4 \mathrm{a}$ & $22.67 \pm 1.67 \mathrm{a}$ \\
4 Sep & $6.27 \pm 0.22 \mathrm{abc}$ & $8.60 \pm 0.10 \mathrm{ab}$ & $782.4 \pm 84.0 \mathrm{a}$ & $22.58 \pm 3.45 \mathrm{a}$ \\
14 Sep & $6.05 \pm 0.28 \mathrm{~b}$ & $8.61 \pm 0.32 \mathrm{ab}$ & $908.8 \pm 85.0 \mathrm{a}$ & $22.54 \pm 1.73 \mathrm{a}$ \\
24 Sep & $5.86 \pm 0.18 \mathrm{c}$ & $8.26 \pm 0.18 \mathrm{~b}$ & $911.4 \pm 54.5 \mathrm{a}$ & $25.16 \pm 0.82 \mathrm{a}$ \\
4 Oct & $6.19 \pm 0.22 \mathrm{abc}$ & $8.92 \pm 0.32 \mathrm{ab}$ & $806.4 \pm 69.6 \mathrm{a}$ & $27.33 \pm 2.33 \mathrm{a}$ \\
\hline
\end{tabular}

Means \pm SE with different letters were significantly different at 0.05 level.

Neither the density nor aboveground biomass of $L$. chinensis were significance during the different cutting dates at the turning green stage (Table 3 ). The density of the first three cutting dates were less than the remaining treatments. The trend of aboveground biomass was ascending as the cutting date delayed. The maximum value was $27.33 \pm 5.20 \mathrm{~g} / \mathrm{m}^{2}$ at the last cutting date.

\subsection{Harvesting Biomass at Middle August in the Second Year}

The three indexes of $L$. chinensis population which we had measured were not significant among the different cutting dates at the harvest time (Table 4). The 
Table 4. The harvesting characteristic of L. chinensis population.

\begin{tabular}{cccc}
\hline Date & Height $(\mathrm{cm})$ & Density $\left(\right.$ plants $\left./ \mathrm{m}^{2}\right)$ & Aboveground biomass $\left(\mathrm{g} / \mathrm{m}^{2}\right)$ \\
\hline 15 Aug & $24.71 \pm 1.07 \mathrm{a}$ & $992.8 \pm 70.6 \mathrm{a}$ & $174.34 \pm 20.59 \mathrm{a}$ \\
$25 \mathrm{Aug}$ & $26.05 \pm 1.90 \mathrm{a}$ & $1079.2 \pm 55.9 \mathrm{a}$ & $166.25 \pm 11.03 \mathrm{a}$ \\
$4 \mathrm{Sep}$ & $24.56 \pm 1.24 \mathrm{a}$ & $1208.4 \pm 85.4 \mathrm{a}$ & $177.23 \pm 16.91 \mathrm{a}$ \\
$14 \mathrm{Sep}$ & $25.19 \pm 1.02 \mathrm{a}$ & $1273.4 \pm 130.4 \mathrm{a}$ & $199.69 \pm 18.20 \mathrm{a}$ \\
$24 \mathrm{Sep}$ & $24.30 \pm 2.20 \mathrm{a}$ & $1355.4 \pm 41.5 \mathrm{a}$ & $192.20 \pm 12.49 \mathrm{a}$ \\
4 Oct & $29.70 \pm 3.61 \mathrm{a}$ & $1259.48 \pm 56.5 \mathrm{a}$ & $194.01 \pm 26.15 \mathrm{a}$ \\
\hline
\end{tabular}

Means \pm SE: with different letters were significantly different at 0.05 level.

highest $L$. chinensis was on October 4 . The character of the density was similar as the turning green stage (Table 3 ), the first three cutting dates were less than the remaining treatments. The maximum aboveground biomass was $199.69 \pm$ $18.20 \mathrm{~g} / \mathrm{m}^{2}$ of the cutting on September $14^{\text {th }}$, and the minimum was $166.25 \pm$ $11.03 \mathrm{~g} / \mathrm{m}^{2}$ of the cutting on August $25^{\text {th }}$.

The species number of the plant community were also few, the species saturation were $10,9,11,12,10$ and 10 , respectively for the cutting dates. The dominant species was $L$. chinensis, which made up the most proportion of the community both in density and aboveground biomass. The dry weight of $L$. chinensis contributed to at least $90 \%$ of the aboveground biomass (Table 4, Figure 2).The main companion species were $K$. integrifolia, L. quinquenervius, $C$. $d u$ riuscula, E. intersita, P. sibiricum. But the aboveground biomass of $L$. chinensis community was not significant among the cutting dates, and they were about $200 \mathrm{~g} / \mathrm{m}^{2}$ (Figure 1).

The coefficients of the community similarity $\left(I S_{s}\right)$ were high for the neighboring two cutting dates, and higher than 0.70 . The highest coefficient was 0.84 between August $15^{\text {th }}$ and August $25^{\text {th }}$, and, they 8 common species.

The values of stem/leaf of $L$. chinensis were not significant different during the cutting dates. And they all were lower than 0.70 , so the weight of the leaves was 1.43 times as much as stems at least. And the cutting date on August $25^{\text {th }}$, the weight of the leaves was next to 2 times as much as stems. The crude protein was form $8.0 \%$ to $9.5 \%$, but there was not significant among the treatments, the companion species contain higher crude protein than $L$. chinensis, which were from $10 \%$ to $12 \%$ (Figure 2).

The Songnen grassland plays an important role in stock raising in northeast China because of its famous for producing $L$. chinensis which has high palatability and quality [4] [5] [17]. The species richness (species number) of the community is small, furthermore, the L. chinensis was absolute predominance (Table 4 and Figure 1). Therefore, the communities were extremely similarly with different cutting dates (Table 5). Mowing in succession years made the aboveground biomass and density descending, the percentage of the high quality herbage in the community decreasing, weeds increasing [25] [26]. In our study, the values of height and aboveground biomass of $L$. chinensis had decreased from 


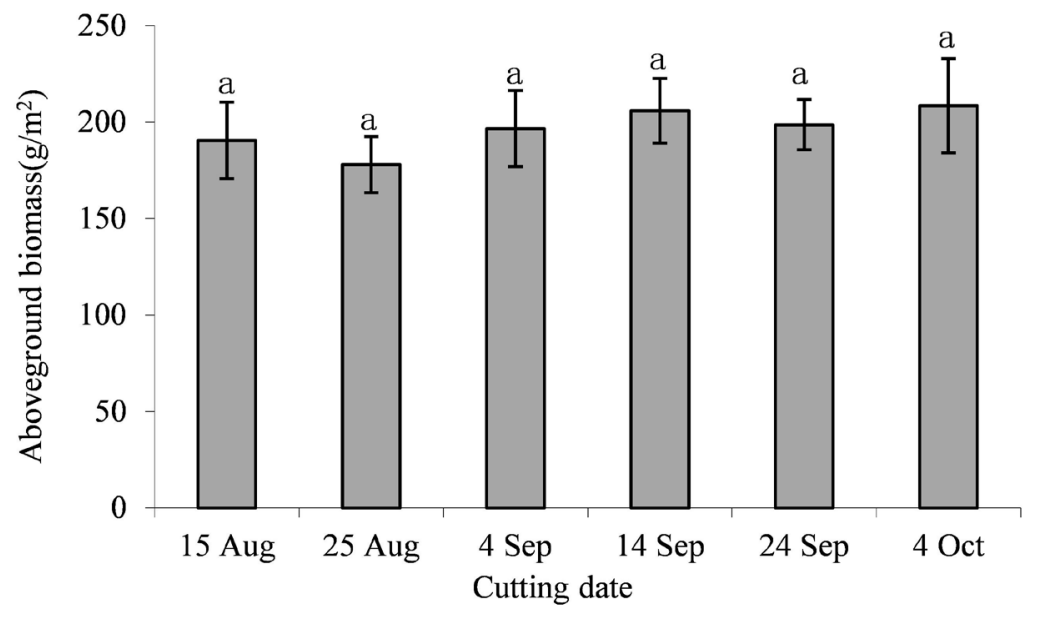

Figure 1. The aboveground biomass of L. chinensis community in August, 2007.

Table 5. The coefficient of the community similarity.

\begin{tabular}{cccccc}
\hline Treatments & 15 Aug - 25 Aug & 25 Aug - 4 Sep & 4 Sep - 14 Sep & 14 Sep - 24 Sep & 24 Sep - 4 Oct \\
\hline$I S_{s}$ & 0.84 & 0.70 & 0.70 & 0.76 & 0.80 \\
\hline
\end{tabular}

2006 to 2007. But the $L$. chinensis proportion was improved after cutting, probably because the rainfall was less in 2007 than 2006, and L. chinensis is more tolerance than other species in the community [5]. The regrowth character also reflected the advantage of $L$. chinensis (Table 1 and Table 2).

The value of stem/leaf was an important index of forage quality, intake, and diet selection [27], usually the value was smaller and the nutrition was higher, because leaf contains more nutrition and is more palatable than stem [28] [29]. The stem/leaf which we measured showed that there was no difference by the different treatments (Figure 2(a)), and the leaves made up a bigger percentage of the aboveground biomass and the quality was fine. And the crude protein percentage was also not significant both $L$. chinensis population and community, so we got the conclusion that autumn different cutting dates didn't influence the quality of the L. chinensis grassland. But the plant community had more crude protein than $L$. chinensis population (Figure 2(b)), because the companion species contained more crude protein, especially the leguminous forage like L. quinquenervius [5].

The aim of cutting in grassland was to gain hay or ensilage [30], thus the harvesting date and forage yield were practical significance [11]. The aboveground biomass of $L$. chinensis population and community were not significant after different cutting dates (Figure 1), and the height, density and stem/leaf were also not significant. This meant that the concentrated harvest dates had the similar influence on the grassland at the remaining stubble was about $5 \mathrm{~cm}$, so when farmers harvested the hay, they just need to consider the factors of weather, labor force, nutrition content and yield of the grassland. The aboveground biomass of L. chinensis reached hump at the middle ten days in August [9], but the 


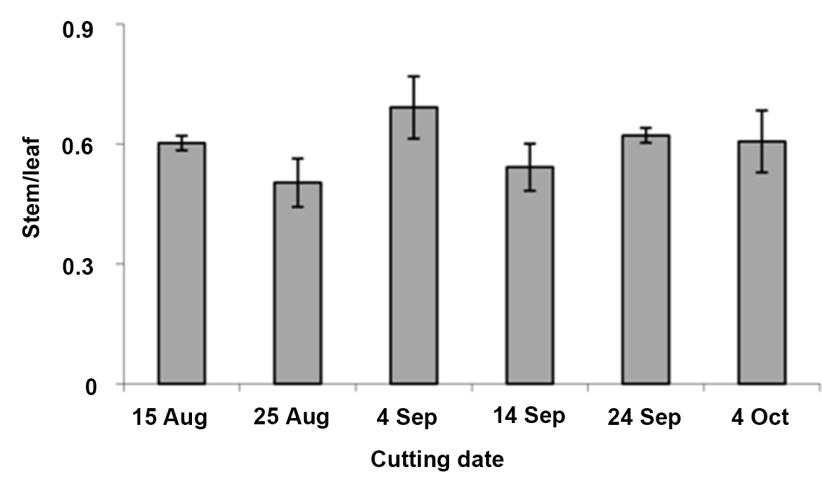

(a)

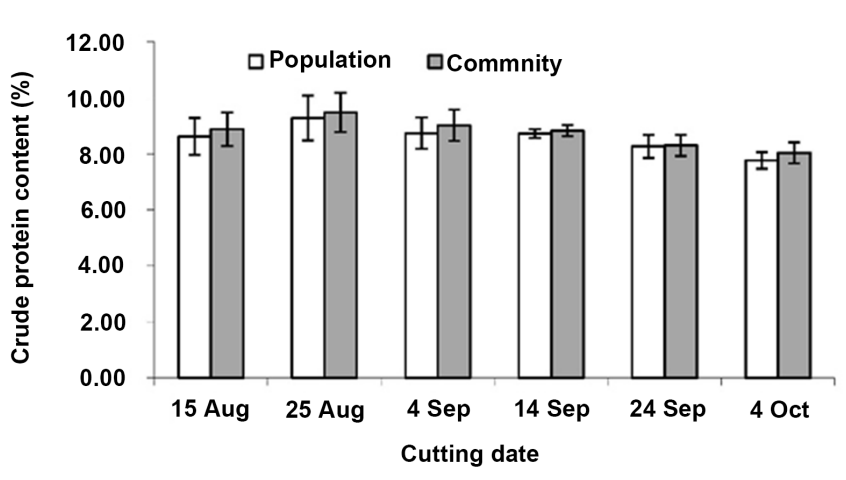

(b)

Figure 2. Forage quality of the (a) stem/leaf of L. chinensis and (b) crude protein of L. chinensis population and community in August.

crude protein decreased and fiber increased after $L$. chinensis turning green, in order to get maximum crude protein, the grassland should be cutting in the last ten days of July [10] [14]. Considering the weather condition in Songnen grassland, we advised that harvest dates should be concentrated from the middle ten days of August to the first ten days in September [5].

Cutting means removing the organics from the grassland [4] [31], the utilization rate of the grassland was less than 50 percent to keep it healthy [25], because plant litter played an important role on the grassland ecosystem [11], and it alters the physical and chemical environment, therefore, it may affect the plant community structure and dynamics [32]. We also investigated the uncut community closed to the experimental plots in 2007, the height, aboveground biomass was significant more than the treatments because of the litter, and the stem/leaf and crude protein were not significant. However, the stand litter would be the obstacle when the farmers mow the grass and decrease the quality of the forage, so the managers need to trade-off the yield and quality, and institute the scientific cutting systems to keep the grassland continuative production.

\section{Conclusion}

The L. chinensis grassland produces herbage superior both in quality and in quantity on the Songnen plain of northeast China, and the L. chinensis makes up about $90 \%$ of the dry aboveground biomass in the L. chinensis community whose species richness is simple. The companion species of $L$. chinensis community contains higher crude protein, but the crude protein of the community is not significant. The coefficients of the community similarity are high. Furthermore the density, height, aboveground biomass, stem/leaf ratio, and crude protein of $L$. chinensis were not significant at the reviving stage and harvesting time. Thus, the harvest dates should be concentrated from the middle ten days of August to the first ten days in September when the weather is fine in this plain. The experiment showed one-year results, and longer-term research is required to get more reliable results. 


\section{Acknowledgements}

The National Science Foundation of China (31500366, 31470504), the Fundamental Research Funds for the Central Universities (No. DC201501070402). Prior Sci-Tech Programs of Overseas Chinese Talents Funds (2015).

\section{References}

[1] Zhou, D.W. and Ripley, E.A. (1997) Environmental Changes Following Burning in a Songnen Grassland, China. Journal of Arid Environments, 36, 53-65. https://doi.org/10.1006/jare.1996.0204

[2] Li, J.D. (1978) Chinese Leymus chinensis (Trin) Kitag. Grassland. Journal of Jilin Normal University, 145-159. https://doi.org/10.16163/j.cnki.22-1123/n.1978.01.017

[3] Zhu, T.C. (2004) Biological Ecology of Aneurolepidium chinense. Jilin Science \& Technology Press, Changchun.

[4] Wang, Z.W., Li, L.H., Han, X.G. and Dong, M. (2004) Do Rhizome Severing and Shoot Defoliation Affect Clonal Growth of Leymus chinensis at Ramet Population Level? Acta Oecologica, 26, 255-260. https://doi.org/10.1016/j.actao.2004.08.007

[5] Zheng, H.Y. and Li, J.D. (1993) The Grassland Vegetation and Its Utilization and Conservation on the Songnen Plains. Science Press, Beijing.

[6] Zhao, J. (2004) Physical Geography of China. Higher Education Press, Beijing.

[7] Schiborra, A., Gierus, M., Wan, H.W., Bai, Y.F. and Taube, F. (2009) Short-Term Responses of a Stipa grandis/Leymus chinensis Community to Frequent Defoliation in the Semi-Arid Grasslands of Inner Mongolia, China. Agriculture, Ecosystems \& Environment, 132, 82-90. https://doi.org/10.1016/j.agee.2009.03.002

[8] Bai, Y.F., Han, X.G., Wu, J.G., Chen, Z.Z. and Li, L.H. (2004) Ecosystem Stability and Compensatory Effects in the Inner Mongolia Grassland. Nature, 431, 181-184. https://doi.org/Doi 10.1038/Nature02850

[9] Chen, J.H., Zu, Y.G., Ni, H.W. and Wang, K. (1998) The Growing Law of Aboveground Biomass of Main Plant Communities in Grazing Field of the Songnen Grassland. Journal of Northeast Forestry University, 26, 49-52.

[10] Guo, J.X., Zhong, W.Y. and Hao, F.Y. (1992) Seasonal Variation of Chinese Wildrye (Leymus chinensis) Nutrition Content. Grassland of China, 5, 8-12.

[11] Li, H., Guo, J.X., Xu, A.C., Xue, F.G. and Li, M. (2000) Effect of Different Clipping Number on Leymus chinensis Grassland in the Songnen Plain of China. Journal of Northeast Normal University, 32, 53-57.

[12] Talle, M., Deak, B., Poschlod, P., Valko, O., Westerberg, L. and Milberg, P. (2016) Grazing vs. Mowing: A Meta-Analysis of Biodiversity Benefits for Grassland Management. Agriculture Ecosystems \& Environment, 222, 200-212. https://doi.org/10.1016/j.agee.2016.02.008

[13] Kunelius, H.T. and Narasimhalu, P.R. (1993) Effect of Autumn Harvest Date on Herbage Yield and Composition of Grasses and White Clover. Field Crops Research, 31, 341-349. https://doi.org/10.1016/0378-4290(93)90072-U

[14] Zhang, H.Y. (1993) The Best Mowing Time of the Leymus chinensis Grassland. Grassland of China, 5, 64-66.

[15] Zhang, W.Z. and Zhang, B.T. (1993) Relationship between Cutting Intensity and Soil Salinization in Leymus chinensis Grasslands. Grassland of China, 4, 4-8. 
[16] Li, J.D. and Liu, J.X. (2000) The Possibility of the Cutting Regime with Two Times per Year on Leymus chinensis. Grassland of China, 5, 32-34.

[17] Wang, R.Z. and Ripley, E.A. (1997) Effects of Grazing on a Leymus chinensis Grassland on the Songnen Plain of North-Eastern China. Journal of Arid Environments, 36, 307-318. https://doi.org/10.1006/jare.1996.0214

[18] Lawrence, D.C., O’Donovan, M., Boland, T.M. and Kennedy, E. (2017) Effects of Autumn and Spring Defoliation Management on the Dry-Matter Yield and Herbage Quality of Perennial Ryegrass Swards throughout the Year. Grass and Forage Science, 72, 38-49. https://doi.org/10.1111/gfs.12226

[19] Giambalvo, D., Amato, G. and Stringi, L. (2011) Effects of Stubble Height and Cutting Frequency on Regrowth of Berseem Clover in a Mediterranean Semiarid Environment. Crop Science, 51, 1808-1814. https://doi.org/10.2135/cropsci2010.05.0271

[20] Zhong, Y.K., Sun, W. and Bao, Q.H. (1998) Effect of Mowing on Leymus chinensis in Typical Steep Region. Acta Scientiarum Naturalium Universitatis Nei Mongol, 29, 202-213.

[21] Clark, P.E., Krueger, W.C., Bryant, L.D. and Thomas, D.R. (1998) Spring Defoliation Effects on Bluebunch Wheatgrass: I. Winter Forage Quality. Journal of Range Management, 51, 519-525. https://doi.org/10.2307/4003368

[22] Reece, P.E., Holman, T.L. and Moore, K.J. (1999) Late-Summer Forage on Prairie Sandreed Dominated Rangeland after Spring Defoliation. Journal of Range Management, 52, 228-234. https://doi.org/10.2307/4003684

[23] Riesterer, J.L., Casler, M.D., Undersander, D.J. and Combs, D.K. (2000) Seasonal Yield Distribution of Cool-Season Grasses Following Winter Defoliation. Agronomy Journal, 92, 974-980. https://doi.org/10.2134/agronj2000.925974x

[24] Sørensen, T. (1948) A Method of Establishing Groups of Equal Amplitude in Plant Sociology Based on Similarity of Species Content and Its Application to Analyses of the Vegetation on Danish Commons. Biologiske Skrifter/Kongelige Danske Videnskabernes Selskab, 5, 1-34.

[25] Zhong, Y.K. and Bao, Q.H. (1999) The Effects of Different Mowing Intensity on Natural Grassland. Grassland of China, 5, 15-18.

[26] Tao, B.Y., Li, F.Y., Minggagud, H., Bao, Q.H. and Zhong, Y.K. (2015) Mowing Succession of Species Composition Is Determined by Plant Growth Forms, Not Photosynthetic Pathways in Leymus chinensis Grassland of Inner Mongolia. Landscape Ecology, 30, 1795-1803. https://doi.org/10.1007/s10980-015-0249-6

[27] Tessema, Z.K., Mihret, J. and Solomon, M. (2010) Effect of Defoliation Frequency and Cutting Height on Growth, Dry-Matter Yield and Nutritive Value of Napier Grass (Pennisetum purpureum (L.) Schumach). Grass and Forage Science, 65, 421-430. https://doi.org/10.1111/j.1365-2494.2010.00761.x

[28] Smart, A.J., Schacht, W.H. and Moser, L.E. (2001) Predicting Leaf/Stem Ratio and Nutritive Value in Grazed and Nongrazed Big Bluestem. Agronomy Journal, 93, 1243-1249. https://doi.org/10.2134/agronj2001.1243

[29] Hurley, G., O’Donovan, M. and Gilliland, T.J. (2009) Effect of Spring Defoliation Pattern on the Mid-Season Production and Morphology of Swards of Perennial Ryegrass Cultivars of Different Maturity. Grass and Forage Science, 64, 80-91. https://doi.org/10.1111/j.1365-2494.2008.00671.x

[30] Moloney, T., O’Riordan, E.G., Sheridan, H. and O'Kiely, P. (2017) The Effects of Defoliating Grass in Winter or Spring on Herbage Yields and Ensilage Characteristics. Grass and Forage Science, 72, 22-37. https://doi.org/10.1111/gfs.12207 
[31] Kaensombath, L. and Frankow-Lindberg, B.E. (2012) Effect of Defoliation Interval on Biomass Yield and Chemical Composition of Stylo "CIAT 184" (Stylosanthes guianensis (Aubl.) Sw. var. guianensis). Grassland Science, 58, 221-226. https://doi.org/10.1111/grs.12004

[32] Violle, C., Richarte, J. and Navas, M.L. (2006) Effects of Litter and Standing Biomass on Growth and Reproduction of Two Annual Species in a Mediterranean Old-Field. Journal of Ecology, 94, 196-205.

https://doi.org/10.1111/j.1365-2745.2005.01061.x 